\title{
EVALUASI PROGRAM PEMBELAJARAN FULL DAY SCHOOL DI SDN BUNULREJO 2 MALANG
}

\author{
Ardyanovanti Rahayu' ${ }^{1}$, Zainul Abidin ${ }^{2}$, Susilaningsih ${ }^{3}$ \\ Universitas Negeri Malang \\ E-mail: ardyadya26@gmail.com
}

\begin{abstract}
ABSTRAK
Program pembelajan full day school merupakan salah satu program SDN Bunulrejo 2 Malang dimana dalam penerapannya terbilang cukup baru. Tujuan dilakukannya penelitian ini yaitu untuk mengetahui ketercapaian program berdasarkan Permendikbud Nomor 23 Tahun 2017 mengenai Hari Sekolah. Penelitian ini menggunakan model evalasi CIPP yang dikembangkan oleh Stufflebeam meliputi Context, Input, Proces, dan Product. Didalam penelitianini peneliti menggunakan metode kualitatif dengan menggunakan teknik pengumpulan data berupa observasi, wawancara, dan studi dokumentasi. Teknik analisis data yang digunakan adalah reduksi data, penyajian data, dan kesimpulan. Dari hasil evaluasi program pembelajaran full day school yang dilakukan di SDN Bunulrejo 2 Malang diperoleh kesimpulan bahwa sekolah tersebut dapat melanjutkan program pembelajaran full day school, karena mampu memberikan manfaat dalam memfasilitasi bakat dan minat siswa serta mampu memenuhi kebutuhan orang tua siswa yang mayoritas adalah pekerja. Berdasarkan hasil evaluasi yang diperoleh, terdapat beberapa rekomendasi yang diberikan agar program pembelajaran full day school di SDN Bunulrejo 2 Malang dapat mencapai tujuan yaitu 1) perlu adanya penambahan ruangan yang digunakan untuk menunjang kegiatan ekstrakulikuler guna menunjang ketercapaian program, 2) perlunya motivasi yang diberikan guru kepada siswa agar memiliki kesadaran tinggi dalam memacu prestasi akademiknya, 3) orang tua siswa perlu adanya kerjasama, dukungan, serta dukungan moril untuk menjadikan pribadi siswa menjadi lebih baik.
\end{abstract}

Kata kunci: Evaluasi Program, Full Day School, CIPP

\section{PENDAHULUAN}

Pendidikan merupakan sarana untuk menentukan kelangsungan hidup pada suatu negara. Menurut Mudyohardjo (2008), pendidikan merupakan pengalaman belajar yang terprogram dalam bentuk formal, non-formal, dan informal. Diselenggarkannya pendidikan sekolah dasar digunakan untuk membekali siswa dalam memberikan keterampilan dan pengetahuan serta mengembangkan sikap dan kemampuan.Sebagai tempat awal menimba ilmu, sekolah dasar diharapkan mampu melaksanakan kegiatan belajar dengan baik, tentunya dengan didukung rancangan pembelajaran yang berkualitas, sehingga pada akhirnya menjadikan siswa yang berkualitas juga. Rancangan pembelajaran yang berkualitas didukung dengan adanya program-program baik dari kebijakan pemerintah maupun kebijakan sekolah Program sekolah yang marak diperbincangkan akhir-akhir ini adalah program pembelajaran full day school. Sulistyaningsih (2008) menyatakan bahwa, "sekolah yang menerapkan full day ini dilaksanakan selama sehari penuh lamanya, yakni dari pukul 07.00 pagi hingga 15.00 sore". Dari program tersebut siswa mendapatkan pelajaran yang lebih lengkap serta padat, Selain itu program full day school menggunakan kurikulum standar nasional yang telah dimodifikasi yang didalamnya ditambahkan kegiatan yang menyenangkan dan inovatif.

Full day school pada umumnya mempunyai kurikulum inti yang sama dengan sekolah umum, namun juga memiliki kurikulum lokal seperti pendidikan karakter, kepemimpinan, pendidikan lingkungan, baca tulis AlQur'an, teknologi informatika dan lainlainya. Dengan demikian kondisi siswa yang mengikuti program tersebut akan lebih menguasai pada segi materi akademik dan non akademik. Banyaknya 
strategi yang dikembangkan pada program full day school, akan membuat siswa menjadi lebih rileks, tidak tergesa-gesa dalam melakukan aktifitas sehari-hari dan memberikan banyak pengalaman yang bervariasi. Secara umum program full day school tercetus dikarenakan adanya berbagai faktor, antara lain sedikitnya waktu yang dimiliki orang tua dikarenkan sibuk bekerja, kurangnya pengawasan dari orang tua, perlu adanya tambahan waktu untuk bidang keagamaan dikarenakan orang tua yang sibuk dengan kegiatannya diluar rumah sehingga minim pengawasan dalam hal keagamaan dan memperbaiki mutu pendidikan.

Pada penerapannya, program pembelajaran full day school memerlukan evaluasi dimana didalamnya akan dilakukan proses pencarian dan penempuan informasi yang di paparkan secara sistematis meliputi perencanaan, nilai, tujuan, manfaat, ketercapaian tujuan dalam konteks pelaksayang telah ditetapkan dengan membandingkan apa yang telah dicapai dari suatu program dengan apa yang seharusnya dicapai berdasarkan kriteria atau standar yang telah ditetapkan sebelumnya. Kriteria yang dimaksud dalam konteks pelaksanaan program adalah kriteria keberhasilan dalam pelaksanakan program tersebut, sedangkan yang dinilai adalah proses dan hasil dari pelaksanaan program yang nantinya akan diambil sebuah keputusan.

Beda jenjang pendidikan beda pula konsep yang diterapkan pada program. Contohnya saja pada jenjang Taman Kanak-Kanak dan pendidikan usia dini memiliki konsep untuk membentuk pribadi anak dalam mengenali dirinya yang selanjutnya akan disebut personal skil, kemudian pada tingkat Sekolah Dasar memiliki konsep untuk membentuk pribadi dalam mengenal potensi yang dimiliki anak tersebut. Berdasarkan perbedaan jenjang tersebut maka seharusnya penerapan konsep program full day school perlu diperhatikan. Anak pada usia Sekolah Dasar adalah usia dimana masa bermain lebih banyak daripada belajar. Oleh karena itu perlu adanya penyesuaian konsep program full day school agar tidak mengambil masa bermain anak dimana masa tersebut mereka gunakan untuk berinteraksi denganlingkungan dan teman sebaya mrekea. kesempatan $\mathrm{m}$. Itulah mengapa perlu adanya evaluasi dalam penerapan program pembelajaran full day school, selain untuk melihat apakah program berjalan efektif serta melihat apakah program pembelajaran full day school sudah mencapai tujuan yang telah dirancang sebelumnya.

Salah satu sekolah yang mengimplementasikan program full day school adalah SDN Bunulerjo 2 Malang. Sekolah ini telah menerapkan program full day school selama dua tahun, yaitu dimulai pada semester 2 tahun ajaran 2016-2017. Waktu kegiatan full day school yang ada di sekolah tersebut dimulai pukul 06.30 sampai pukul 15.30. Kegiatan yang dilaksanakan pada program tersebut yaitu melaksanakan Kurikulum 2013 secara konsisten dan penguatan pendidikan karakter. Sekolah tersebut masih cukup baru dalam mengimplementasikan program full day school. Oleh karena itu diperlukan evaluasi untuk melihat berhasil atau tidaknya program full day school di sekolah tersebut.

Dari latar belakang yang ada, peneliti mengambil penelitian di sekolah tersebut, sehingga judul dari skripsi ini adalah "Evaluasi Program Pembelajaran Full Day School di SDN Bunulrejo 2 Malang".

Berdasarkan judul skripsi yang ditentuka adapun tujuan yang ingin didapat dalam melakukan penelitian ini yaitu mendeskripsikan hasil evaluasi pada aspek konteks, masukan, proses, dan hasil diimplementasikannya program pembelajaran full day school yang diterapkan di SDN Bunulrejo 2 Malang yang kemudian akan diambil keputusan. 


\section{METODE PENELITIAN}

Penelitian ini menggunakan metode kualitatif dengan menggunakan model evaluasi CIPP yang dibuat oleh Stufflebeam (2002) meliputi context, input, proces, dan product.

1. Context evaluation (evaluasi terhadap konteks): dalam tahap ini peneliti akan menggambarkan tentang ketentuan program full day school, latar belakang diterapkannya program, dan tujuan program pembelajaran full day school di SDN Bunulrejo 2

2. Input evaluation (evaluasi terhadap masukan): yang dimaksud masukan disini adalah kurikulum atau materi yang digunakan, kegiatan korikuler sekolah, pendidik yang terlibat didalam program, serta sarana dan prasarana sekolah digunakan saat melaksanakan program pembelajaran full day school.

3. Proses evalution (evaluasi terhadap proses): dalam tahap ini peneliti akan melihat jadwal pelaksanaan program, strategi yang digunakan untuk mempermudah proses pelaksanaan program, serta beban kerja guru dalam pembelajaran.

4. Product evaluation (evaluasi terhadap hasil): dalam tahap ini peneliti akan melihat hasil dari penerapan program tersebut, seperti pengaruh dari diterapkannya program dan prestasi yang diperoleh oleh siswa.

Sumber data yang digunakan peneliti adalah data primer dan data sekunder. Untuk data primer diambil dari data melalui wawancara dan observasi yang dilakukan peneliti dengan informan yang meliputi kepala sekolah, guru kelas, siswa, dan orang tua siswa. Sedangkan untuk data sekunder adalah data yang digunakan untuk melengkapi data primer yaitu berupa dokumen-dokumen yang berkaitan dengan penelitian.

Teknik pengumpulan data dalam penelitian ini menggunakan observasi, wawancaram dan studi dokumentasi. Sedangkan teknik analisis data yang digunakan peniliti adalah reduksi data, penyajian data, dan kesimpulan. Untuk teknik pemeriksaan keabsahan data peneliti menggunakan tiga teknik oemeriksaan yaitu (1) perpanjangan keikutsertaan dilakukan dengan cara memaksimalkan waktu wawancara, (2) ketekunan pengamatan dilaksanakan dengan menfokuskan perhatian pada masalah yang diteliti secara rinci, (3) triangulasi sumber dilakukan dengan cara mengadakan pengecekan silang hasil wawancara antar subjek penelitian dan triangulasi teknik dilakukan dengan cara mengadakan pengecekan silang hasil wawancara dengan hasil observasi, dan dokumentasi.

\section{HASIL DAN PEMBAHASAN}

\section{Evaluasi Konteks (Context) Program Pembelajaran Full Day School}

Dalam penyelenggaraan program pembelajaran full day school yang dilakukan di SDN Bunulrejo 2 Malang, sekolah mengacu pada Permendikbud Nomor 23 Tahun 2017 mengenai Hari Sekolah. Selain itu sekolah juga mengacu pada Permendikbud No 57 tahun 2014 mengenai Kurikulum 2013 Sekolah Dasar / Madrasah Ibtidaiyah dan Perpres No. 87 Tahun 2017 mengenai Penguatan Pendidikan Karakter (PPK).

Selanjutnya terdapat dua hal yang melatarbelakangi program pembelajaran full day school di SDN Bunulrejo 2 Malang, pertama mayoritas wali murid yang bekerja menginginkan anaknya untuk bisa memanfaatkan waktu dengan baik tentunya dengan pengawasan lebih dari pihak sekolah serta perlunya diterapkan pendidikan karakter kepada siswa mengingat karakter siswa sekarang berbeda dengan dahulu. Untuk tujuan, sekolah memiliki tujuan dengan memberikan kesempatan kepada siswa untuk memfasilitasi bakat dan minat anak agar tersalurkan dengan baik. 
Menurut Arikunto dan Cepi Safrudin (2008), evaluasi konteks dilakukan untuk memperlihatkan lingkungan kebutuhan yang belum terpenuhi selama melaksanakan program, tujuan apa yang belum tercapai, tujuan mana yang berhubungan dengan pemenuhan kebutuhan, dan tujuan mana yang mudah dicapai. Berdasarkan hasil analisis ketercapaian evaluasi pada aspek konteks diperoleh kategori tinggi yang dapat disimpulkan bahwa aspek konteks pada program pembelajaran full day school di SDN Bunulrejo 2 Malang sudah baik dan cukup sesuai mengingat sekolah menerapkan program berdasarkan peraturan pemerintah dan kebutuhan masyarakat serta mencapai tujuan yang direncanakan.

\section{Evaluasi Masukan (Input) Program Pembelajaran Full Day School}

Komponen masukan (input) menurut Widyoko (2015) meliputi sumber daya yang ada dan prosedur kerja dalam mencapainya. Dari paparan data yang disajikan pada aspek masukan terdapat komponen berupa kurikulum atau matei yang digunakan, kegiatan yang diterapkan, pendidik yang terlibat serta sarana dan prasarana yang ada di SDN Bunulrejo 2 Malang sudah cukup baik.

Pertama pada segi kurikulum atau materi, sekolah menggunakan mata pelajaran wajib dan pendidikan penguatan karakter yang diselipkan disetiap kegiatan pembelajaran, kedua kegiatan yang dilakukan di sekolah tidak hanya kegiatan pembelajaran di kelas atau kegiatan tatap muka saja akantetapi juga terdapat kegiatan kokurikuler yang dilakukan untuk pendalaman atau penguatan kompetensi serta kegiatan ekstrakulikuler yang digunakan untuk memanfaatkan waktu anak secara efektif agar bakat dan minat anak tersalurkan dengan baik, ketiga dari segi terlibatnya pendidik selain guru, kepala sekolah, dan staf administrasi dalam program pembelajaran full day school.
Namun terdapat hal yang perlu diperbaiki lagi yaitu pada komponen sarana dan prasarana yang belum sepenuhnya menunjang kegiatan dalam program. Hal tersebut sesuai dengan hasil analisis ketercapaian program pada aspek masukan yang diperoleh kategori sedang yang membuktikan bahwa sekolah kekurangan ruangan untuk melaksanakan kegiatan ekstrakulikuler serta pembinaan bakat dan minat. Kegiatan tersebut sering dilakukan di teras sekolah, ruang perpustakaan, atau menunggu ruang kelas yang kosong untuk digunakan melaksanakan kegiatan. Hasil tersebut menjadi masukan bagi program pembelajaran full day school di SDN Bunulrejo 2 Malang agar meningkatkan aspek input terutama pada komponen sarana dan prasarana. Sekolah perlu mengadakan penambahan ruangan atau tempat khusus yang digunakan untuk menunjangr kegiatan ekstrakulikuler serta pembinaan bakat dan minat agar dapat menunjang berjalannya program pembelajaran full day school yang diterapkan.

\section{Evaluasi Proses (Proces) Program Pembelajaran Full Day School}

Pada aspek proses meliputi komponen jadwal kegiatan, strategi yang digunakan serta pelaksanaan beban kerja guru. Untuk kegiatan pembelajaran dilaksanakan selama 5 hari dan 8 jam dalam sehari. Hal tersebut sesuai dengan peraturan Permendikbud Nomor 23 Tahun 2017 mengenai Hari Sekolah yang menyebutkan bahwa hari sekolah dilakukan selama 8 (delapan) jam dalam 1 (satu) hari atau 40 (empat puluh) jam selama 5 (lima) hari dalam 1 (satu) minggu.

Menurut Sanjaya (2006) dalam mengimplementasikan sebuah rencana perlu adanya metode yang digunakan dalam mencapai tujuan yang disusun. Hal tersebut sejalan dengan adanya strategi yang digunakan di SDN Bunulrejo 2 Malang. Dalam mempermudah proses pembelajaran sekolah menggunakan 
strategi berupa adanya kerjasama dengan orang tua serta penggunaan variasi metode serta media pembelajaran yang digunakan guru guna meminimalisir kejenuhan belajar siswa.

Selanjutnya untuk komponen beban guru juga sesuai dengan ketentuan Permendikbud Nomor 23 Tahun 2017 mengenai Hari Sekolah. Pada komponen tersebut guru di SDN Bunulrejo 2 Malang telah merencanakan kegiatan

pembelajaran berupa penyusunan RPP, media yang digunakan, serta model evaluasi apa yang digunakan pada setiap kegiatan pembelajaran. Selanjutnya guru melaksanakan pembelajaran yang diawali dengan pembiasan berupa do'a bersama, asmaul husna, serta menyanyikan lagu wajib nasional atau lagu daerah. Kemudian dilanjutkan dengan bimbingan yang dilakukan guru kepada siswa melalui kegiatan apersepsi dan kegiatan pembelajaran inti. Terakhir guru melakukan evaluasi dan menilai hasil pembelajaran siswa pada kegiatan pembelajaran inti.

Dilihat dari analisis ketercapaian program pada aspek proses didapatkan kategori tinggi yang dapat disimpulkan bahwa program pembelajaran full day school di SDN Bunulrejo 2 Malang sudah memenuhi kategori aspek proses dengan baik dan ada baiknya dipertahankan dan ditingkatkan kembali.

\section{Evaluasi Hasil (Product) Program Pembelajaran Full Day School}

Berdasarkan analisis ketercapaian program yang dilakukan oleh peneliti, pada aspek hasil program mendapatkan kategori tinggi pada komponen bakat minat yang terfasilitasi serta komponen prestasi non akademik yang diperoleh oleh siswa, namun mendapatkan kategori rendah pada komponen terdapatnya pekerjaan rumah dan komponen prestasi akademik yang dimiliki siswa. Hal tersebut menjadi masukan bagi SDN Bunulrejo 2 Malang untuk lebih memotivasi siswa dalam mengikuti kompetisi di bidang akademik dengan memaksimalkan pembelajaran akademik agar terjadi keseimbangan antara prestasi akademim maupun non akademik.

Selanjutnya pada komponen kejenuhan siswa diperoleh kategori sedang dimana masih didapati siswa yang lelah dan jenuh dalam berlangsungnya pembelajaran. Akan tetapi guru memberikan variasi metode dan media dalam pembelajaran, kemudian juga diberikannya ice breaking kepada siswa. Sejalan dengan pendapat Syah (1999) yang mengungkapkan mengenai upaya yang bisa dilakukan untuk mengatasi rasa bosan dalam belajar.

\section{PENUTUP}

Dalam pelaksanaan program pembelajaran full day school harus memperhatikan konteks, masukan, proses, dan hasil. Pertama pada aspek konteks (context), sudah memenuhi syarat dimana 3 kriteria pada aspek konteks mendapat kategori tinggi meliputi terdapatnya landasan yang mengatur program serta adanya latar belakang dan tujuan program yang mendukung kebutuhan masyarakat.

Kedua pada aspek masukan (input), belum semua komponen tercapai. Dari 8 kriteria aspek masukan terdapat 5 kriteria dengan kategori tinggi, 2 kriteria dengan kategori sedang, dan 1 kriteria dengan kategori rendah. Rendahnya ketersediaan ruangan untuk menunjang kegiatan ekstrakulikuler serta pembinaan bakat dan minat merupakan salah satu hambatan dalam ketercapaian program pembelajaran full day school. Akan tetapi sekolah mensiasati dengan menggunakan lapangan, ruang perpustakaan, serta ruangan kelas yang kosong untuk dijadikan tempat untuk melaksanakan kegiatan ekstrakulikuler tersebut.

Ketiga pada aspek proses (proces), sudah terpenuh dimana didapati kategori tinggi pada kelima kriteria aspek proses. Jadwal kegiatan dilaksanakan selama 5 hari, 8 jam dalam 1 hari. Selanjutnya terdapat strategi untuk mempermudah 
berjalannya program seperti kerjasama yang dilakukan sekolah dengan orangtua siswa serta adanya variasi metode dan media yang digunakan guru dalam proses belajar mengajar. Kemudian juga sesuainya beban kerja guru terlaksananya beban kerja guru.

Keempat pada aspek hasil (product), dari 5 kriteria belum semua kriteria tercapai. Meskipun bakat dan minat siswa tersalurkan melalui kegiatan ekstrakulikuler dan sering mendapati prestasi non akademik, sekolah masih jarang mendapatkan prestasi akademik dan masih memberikan pekerjaan rumah yang membuat siswa lelah. Akan tetapi guru tetap mengupayakan cara untuk membuat siswanya terlepas dari rasa lelah dan jenuh

Setelah adanya evaluasi program pembelajaran ini, diharapkan sekolah mempertahankan dan meningkatkan kembali pelaksanaan program pembelajaran full day school seperti saat ini dan perlu adanya penambahan ruangan yang digunakan untuk menunjang kegiatan ekstrakulikuler guna menunjang ketercapaian program pembelajaran full day school yang telah direncanakan. Selain itu hendaknya meminimalisir pekerjaan rumah yang diberikan kepada siswa mengingat siswa sudah belajar seharian penuh disekolah agar mengurangi rasa lelah dan jenuh yang dialami oleh siswa. Untuk strategi yang digunakan guru berupa variasi metode dan media pembelajaran perlu dipertahankan untuk memberikan motivasi kepada siswa agar lebih antusias dalam kegiatan pembelajaran. Selain itu guru juga perlu memotivasi siswa agar memiliki kesadaran yang tinggi dalam memacu prestasi akademiknya. Terakhir perlu adanya pengawasan yang dilakukan oleh pihak orang tua siswa terhadap kegiatan yang dilakukan oleh siswa serta dukungan moril untuk menjadikan pribadi siswa kearah yang lebih baik.

\section{DAFTAR PUSTAKA}

Arikunto, Suharsimi dan Abdul Jabar, Cepi Safrudin. (2008). Evaluasi

Program pendidikan. Jakarta: PT. Bumi Aksara.

Mudyahardjo, Redja. (2008). Pengantar Pendidikan: Sebuah Studi Awal tentang Dasar-Dasar Pendidikan pada Umumnya dan Pendidikan di Indsonesia. Jakarta: PT. Grafindo Persada.

Permendikbud Republik Indonesia Nomor 23 Tahun 2017 Tentang Hari Sekolah.

Sanjaya, W. (2006.) Strategi Pembelajaran Berorientasi Standar Proses Pendidikan. Jakarta: Kencana Predana Media Group.

Sulistyaningsih, Wiwik. (2008). Full Day School dan Optimalisasi Perkembangan Anak. Yogyakarta: Paradigma Indonesia.

Stufflebeam, Daniel L dan kawan-kawan. (2002). Evaluation in Education and Human Service. Buston: Academic Puublisher.

Syah, Muhibbin.(1999). Psikologi Belajar. Jakarta: PT. Logos Wacana Ilmu.

Widyoko, Eko Putro. (2015). Evaluasi Program Pembelajaran. Available on

http:www.umpwr.ac.id/download/p ublikasiilmiah/Evaluasi\%20Progra m\%20Pembelajaran.pdf. Diambil 19 November 2017 